\title{
ODONATE ABUNDANCE AND DIVERSITY IN FOUR SELECTIVE SPOTS OF CHITTAGONG UNIVERSITY CAMPUS
}

\author{
Nasiruddin, M. and A. Barua \\ Department of Zoology, University of Chittagong, Chittagong 4331, Bangladesh
}

\begin{abstract}
The abundance and diversity of odonate fauna were studied in four selective spots of Chittagong University Campus, Chittagong, Bangladesh from August'2016 to July'2017. A total of 928 individuals of odonates under three families was collected during the study period from the four sampling sites. Out of 25 species identified one belonged to the family Gomphidae, 13 belonged to family Libellulidae and 11 belonged to family Coenagriidae. The abundance of odonate species was highest in July'17 (13.04\%) and was lowest in December' 16 (4.96\%). Spot 2 was a hotspot for odonates as highest number (370) was collected from this spot. A total of 196, 188 and 174 individuals were collected from Spot 4, Spot 3 and Spot 1, respectively. The members of Libellulidae (472) were dominant followed by Coenagriidae (406) and lastly Gomphidae (50). Highest species richness (SR), species diversity $\left(\mathrm{H}^{\prime}\right)$ and species evenness $\left(\mathrm{J}^{\prime}\right)$ values were observed in the months of May'17 (1.56 \pm 0.08$)$, May'17 (1.29 \pm 0.08$)$ and December'16 (0.96 \pm 0.03$)$, respectively. But lowest such values were observed in December'16 $(0.96 \pm 0.05)$, November'16 $(0.90 \pm 0.02)$ and May'17 $(0.81 \pm 0.05)$,

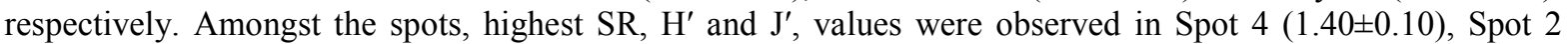
$(1.22 \pm 0.05)$ and Spot $1(0.93 \pm 0.02)$, respectively, whereas, lowest such values were observed in Spot 1 $(1.02 \pm 0.08)$, Spot $1(1.01 \pm 0.04)$ and Spot $4(0.82 \pm 0.02)$, respectively. Ecological conditions and seasonal fluctuation had great impact on the abundance and diversity of odonates.
\end{abstract}

Key words: Odonate fauna, abundance, distribution, diversity, diversity indices.

\section{INTRODUCTION}

Odonates are very ecologically important insects occupying both aquatic and terrestrial habitats. Insects belonging to the Odonata are vital biological indicators of the habitats they live in. the odonates belong to paleopterous and amphibiotic insect group found in all continents except Antartica (Silsby 2001, Mitra 2002, Tsuda 2000, Lahiri 1987, Biswas et al. 1990, Kumar and Prasad 1981, Trueman 2007). A total of 6050 species of Odonata belonging to 600 genera has been recorded throughout the world (Vick 2002).

Bangladesh is of enormous interest in terms of Zoogeography as it is the delta of the Himalayas. The entire country is a very suitable place for breeding of odonates (Begum et al. 1990a, 1990b, Bashar et al. 2014). Bangladesh contains wetlands including rivers, lakes and ponds. Moreover, in monsoon heavy rainfall creates many temporary water bodies. These temporary water resources act as breeding ground for odonate species (Chowdhury and Mohiuddin 1994). In addition to the permanent and temporary stagnant water bodies, a good number of waterfalls and streams exist in the north-east and the south-east part of the country. Such diversification of water bodies along with presence of many tropical forests has created a very rich and suitable breeding place for the dragonflies and damselflies.

Despite of the ambient environment, ironically, scanty research on diversity has been carried out to document odonate fauna of Bangladesh. Some important works on different aspects of odonate fauna in different parts of Bangladesh are those of Chowdhury and Zenther (1971), Chowdhury and Akhteruzzaman (1983), Chowdhury and Miah (1989), Chowdhury and Mohiuddin (1993), Nomura and Alam (1995), Chowdhury and Mohiuddin (2011), Bashar et al. (2014), Khan (2015), Khan (2017) and Tuhin and Khan (2018). Total number of odonate species found in Bangladesh are yet unknown (Bashar et al. 2014). Experts feel that the total number of odonate species of Bangladesh may exceed 150, of 
which only 62 species have so far been put on record in "Dragonfllies and Damselflies of Bangladesh" (Habib et al. 2016).

The present work is an effort to list some of the representatives of odonate fauna in the four selected areas of Chittagong University Campus. The study is aimed to compare their abundance throughout the study period and also to see the distribution and diversity of the studied families in the selected areas of the university campus.

\section{MATERIAL AND METHODS}

Odonate species were collected from four different areas of Chittagong University Campus. The studied spots were: Spot 1(Biological Science Faculty pond area), Spot 2 (Hill Bottom Colony pond area), Spot 3 (A pond area behind the Institute of Marine Science and Fisheries) and Spot 4 (Arts faculty jhupri pond area). The temperature of the study spots was ranges from $19-28^{\circ} \mathrm{C}$ and the RH was $58-86 \%$.

Spot 1 was enriched with different types of herbs and shrubs, such as tulsi (Ocimum sanctum), senna (Casia augustifora), kakamachi (Solanum nigrum), basil (Ocimum basilicum), brahmi (Centella asiatica) etc. Some other important vegetations of this spot included khejur (Phoenix sylvestries), uri ghas (Oryza coarctata), asamlata (Eupatoeium odoratum), pteris (Pteris cretica), kolmilata (Imomoea spp.), koroi (Albizia spp.), bean (Lablab purpureus), radish finger (Raphanus sativa) etc. Spot 2 was highly enriched with aquatic vegetations mainly kolmilata (Ipomoea spp.), dolkolmi (I. fistulosa), helenchha (Enhydra fluctuans), small water lily (Nymphoides indicum), water hyacinth (Eichornia crassipes), water lettuce (Araceae spp.) etc. Around the pond there were some plants, such as guava (Psidium guajava), lemon (Citrus limon) and vegetable plants named pumpkin (Cucurbita pepo), bottle gourd (Lagenaria siceraria), bitter gourd (Momordica charantia), ridged gourd (Luffa acutangula) etc. There were some fields surrounding Spot 3. Seasonal vegetables were cultivated in those fields during winter and in other seasons paddy was cultivated. The cultivated vegetable plants during winter and other seasons were ridged gourd (Luffa acutangula), snake gourd (Trichosanthes cucumerina), bottle gourd (Lagenaria siceraria), bitter gourd (Momordica charantia), bean (Lablab purpureus), lady's finger (Abelmos cusesculentus), tomato (Solanum lycopersicum), brinjal (Solanum melongena), cucumber (Cucumis sativus), cow pea (Vigna sinensis) etc. In Spot 4, there was some large trees, such as koroi (Albizia spp.), arjun (Terminalia arjuna), sissoo (Dalbergia sissoo) at the bank of the pond. Besides these, there were banana trees (Musa acuminata), bamboo (Bambusa vulgaris) and vegetable plants, such as pumpkin (Cucurbita pepo), ridged gourd (Luffa acutangula), spiny gourd (Momordica dioica), green pepper (Capsicum annuum) etc. There were also some climbing plants, herbs and grasses.

During the study, odonate specimens were collected once in a month from each sampling site mainly in the morning hours. In each spot, the sampling duration lasted for an hour. Sweeping process was used for the collection of sample and insect sweeping net was used for this purpose. Collected specimens were then killed, sorted, pinned, labeled, dried and preserved following general entomological procedures. Identification was done following Fraser (1933, 1934 and 1936), Richards and Davies (1977) and Borror et al. (1981). Encyclopedia of Flora and Fauna of Bangladesh (Kabir et al. 2008) and internet sources were also consulted for identification.

The observed and collected insects per species were recorded in each month for each spot. The total number of species collected per month/ per spot/ per genus / per family was counted as percentage for determining the abundance of insects for each month/ spot/ family. Three diversity indices were applied to investigate the richness, diversity and evenness of the odonates in the four spots.

Species richness was calculated as per calculated as per Gleason (1922), Franz (1976) as-

$$
\mathrm{SR}=\mathrm{S}-1 / \log \mathrm{N}
$$

Where $S=$ Total number of species in a sample.

$\mathrm{N}=$ Natural log of total number of individuals of all species 
Shannon-Wiener's species diversity index $\left(H\right.$ or $\left.H^{\prime}\right)$ incorporates both species richness and equitability. The formula of Shannon-Wiener (1949) diversity index is

$$
H^{\prime}=-\sum_{i=1}^{s}\left(p i \log _{2} p i\right)
$$

Where, $s=$ Total number of species in a sample

$p i=$ Proportion of the population $=$ Number of individual of one population $\div$ total individual of the community

Species evenness $\left(J^{\prime}\right)$ is a measure of equitability, a measure how evenly the individuals are distributed among the different species as per Pielou (1966).

$$
J^{\prime}=H^{\prime} / \log _{2} S
$$

Where, $J^{\prime}=$ Species evenness

$H^{\prime}=$ Species diversity

$S=$ Number of species

\section{RESULTS AND DISCUSSION}

During the study period dragonflies and damselflies of order Odonata were collected and identified. A total of 928 individuals of Odonates belonging to the two suborders Anisoptera and Zygoptera was collected. A total of 25 species of both the suborders was recorded and identified which are enlisted in Table 1.

\begin{tabular}{|c|c|c|c|}
\hline Suborder & Family & Scientific Name & Common Name \\
\hline \multirow{14}{*}{ Anisoptera } & Gomphidae & Ictinogomphus rapax (Rambur, 1842) & Common Clubtail \\
\hline & \multirow{13}{*}{ Libellulidae } & Rhyothemis variegata (Linnaeus, 1763) & Common Picturewing \\
\hline & & Neurothemis tullia (Drury, 1773) & Pied-paddy Skimmer \\
\hline & & Neurothemis fulvia (Drury, 1773) & Fulvous Forest Skimmer \\
\hline & & Brachythemis contaminata (Fabricius, 1793) & Ditch Jewel \\
\hline & & Brachidiplax sobrina (Rambur, 1842) & Little Blue Marsh Hawk \\
\hline & & Brachidiplax chalybea (Brauer, 1868) & Rufous-backed Marsh Hawk \\
\hline & & Rhodothemis rufa (Rambur, 1842) & Rufous Marsh Glider \\
\hline & & Acisoma panorpoides (Rambur, 1842) & Trumpet Tail \\
\hline & & Trithemis festiva (Rambur, 1842) & Black Marsh Glider \\
\hline & & Crocothemis servilia (Drury, 1773) & Scarlet Skimmer \\
\hline & & Palpopleura sexmaculata (Fabricius, 1935) & Blue-tailed Yellow Skimmer \\
\hline & & Orthetrum sabina (Drury, 1770) & Green Marsh Hawk \\
\hline & & Diplacodes trivialis (Rambur, 1842) & Ground Skimmer \\
\hline \multirow{11}{*}{ Zygoptera } & \multirow{11}{*}{ Coenagriidae } & Ceriagrion cerinobellum (Brauer, 1865) & Orange-tailed Marsh Dart \\
\hline & & Ceriagrion coromandelianum (Fabricius, 1798) & Coromandel Marsh Dart \\
\hline & & Ceriagrion fallax (Ris, 1914) & Black-tailed Marsh Dart \\
\hline & & Copera annulata (Selys, 1863) & Narrow-winged Damselfly \\
\hline & & Copera vittata (Selys, 1863 ) & Blue Bush Dart \\
\hline & & Copera ciliata (Seyls, 1863) & Black-kneed Featherlegs \\
\hline & & Ischnura aurora (Brauer, 1865) & Golden Dartlet \\
\hline & & Mortonagrion aborense (Laidlaw, 1914) & Not available \\
\hline & & Agriocnemis pygmaea (Rambur, 1842) & Pygmy Dartlet \\
\hline & & Agriocnemis femina (Brauer, 1868) & Pruinosed Dartlet \\
\hline & & Agriocnemis lacteola (Seyls, 1877) & Milky Dartlet \\
\hline
\end{tabular}

Table 1. List of odonate species collected during the study period.

From the study (Fig. 1) it is seen that odonate species abundance was high in the months of July'17 $(13.04 \%)$ and September'16 (11.64\%) and their abundance was low in the months of January'17 $(5.60 \%)$, November $(5.39 \%)$ and December $(4.96 \%)$. Among all months (Table 2), the abundance of libellulid species was comparatively higher in the months of Aug'16 to Dec'16, Jun'17 and Jul'17 and 
coenagrioniid species was comparatively higher in the months of Jan'17 to Jun'17. Of the total collected species, libellulid species were most abundant (50.86\%) followed by coenagrioniid species (43.75\%) and gomphid species were least in abundance comprising only 5.39\% of the total collection (Table 2).

Table 2. The month-wise distribution and abundance of collected odonate species in the study spots.

\begin{tabular}{lccccc|cccccc|cccc}
\hline Month & \multicolumn{4}{c}{ Family: Gomphidae } & \multicolumn{4}{c|}{ Family: Libellulidae } & \multicolumn{4}{c}{ Family: Coenagriidae } \\
\cline { 2 - 15 } & Spot & Spot & Spot & Spot & Total & Spot & Spot & Spot & Spot & Total & Spot & Spot & Spot & Spot & Total \\
& $\mathbf{1}$ & $\mathbf{2}$ & $\mathbf{3}$ & $\mathbf{4}$ & & $\mathbf{1}$ & $\mathbf{2}$ & $\mathbf{3}$ & $\mathbf{4}$ & & $\mathbf{1}$ & $\mathbf{2}$ & $\mathbf{3}$ & $\mathbf{4}$ & \\
\hline Aug'16 & 0 & 3 & 0 & 2 & 5 & 7 & 14 & 13 & 13 & 47 & 4 & 15 & 7 & 5 & 31 \\
Sep'16 & 0 & 4 & 0 & 2 & 6 & 11 & 28 & 13 & 17 & 69 & 5 & 11 & 9 & 8 & 33 \\
Oct'16 & 0 & 1 & 0 & 0 & 1 & 11 & 21 & 10 & 10 & 52 & 8 & 12 & 5 & 2 & 27 \\
Nov'16 & 0 & 0 & 0 & 0 & 0 & 7 & 14 & 7 & 5 & 33 & 3 & 9 & 3 & 2 & 17 \\
Dec'16 & 0 & 0 & 0 & 0 & 0 & 4 & 10 & 5 & 7 & 26 & 5 & 7 & 5 & 3 & 20 \\
Jan'17 & 0 & 2 & 0 & 1 & 3 & 6 & 9 & 4 & 6 & 25 & 4 & 12 & 3 & 5 & 24 \\
Feb'17 & 0 & 3 & 2 & 1 & 6 & 5 & 11 & 4 & 5 & 25 & 8 & 13 & 10 & 9 & 40 \\
Mar'17 & 0 & 5 & 3 & 1 & 9 & 8 & 13 & 3 & 7 & 31 & 9 & 11 & 9 & 6 & 35 \\
Apr'17 & 0 & 0 & 0 & 2 & 2 & 6 & 10 & 5 & 6 & 27 & 8 & 18 & 11 & 11 & 48 \\
May'17 & 2 & 3 & 1 & 3 & 9 & 5 & 15 & 4 & 8 & 32 & 11 & 16 & 12 & 4 & 43 \\
Jun'17 & 1 & 2 & 0 & 0 & 3 & 7 & 16 & 8 & 10 & 41 & 8 & 15 & 7 & 7 & 37 \\
Jul'17 & 0 & 3 & 1 & 2 & 6 & 9 & 26 & 12 & 17 & 64 & 12 & 18 & 12 & 9 & 51 \\
\hline Total & 3 & 26 & 7 & 14 & 50 & 86 & 187 & 88 & 111 & 472 & 85 & 157 & 93 & 71 & 406 \\
\hline
\end{tabular}

Highest species abundance spot was observed to be Spot $2(39.87 \%)$ and the abundance of collected species was lesser in number, but almost the same in the other three spots, i.e. Spot 4 (21.12\%), Spot 3 $(20.26 \%)$ and Spot 1 (18.75\%) (Fig. 2). In all the spots, the abundance of libellulid species was higher than coenagrioniid species and gomphid species was least abundant (Fig. 4) than that of the other two families.

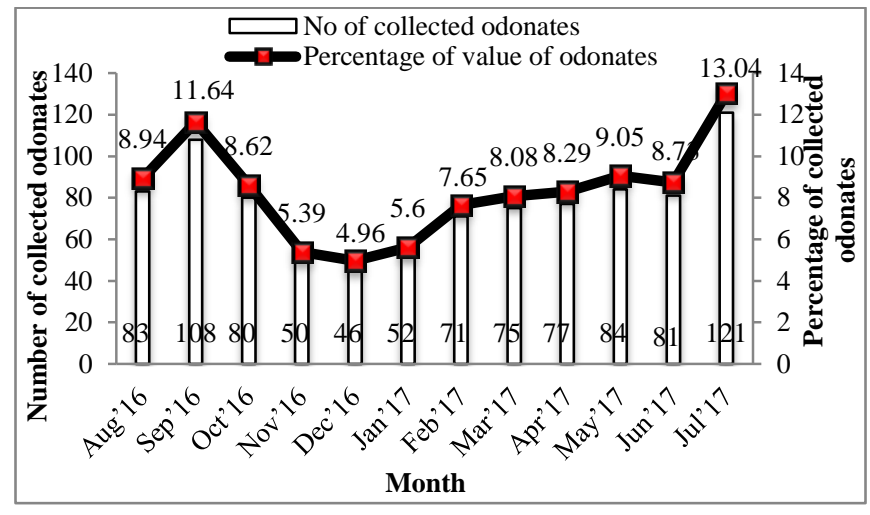

Fig. 1. Month-wise numbers and percentage values of odonate species collected during the study period.

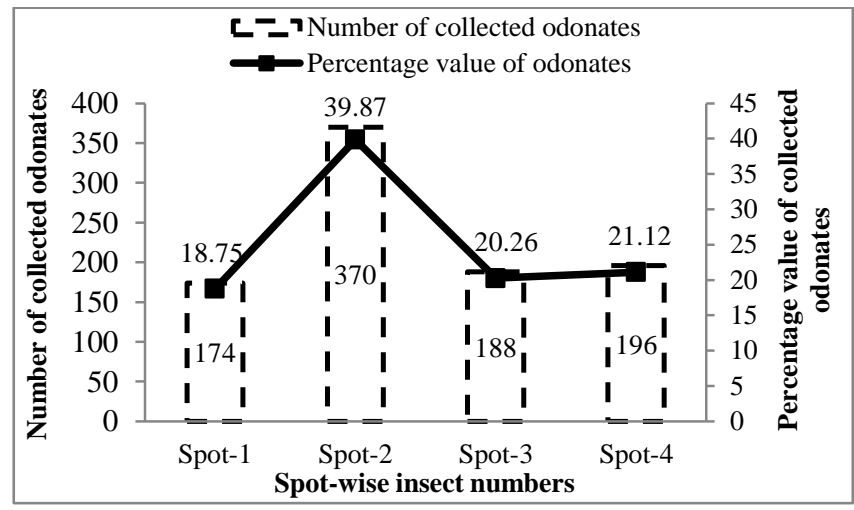

Fig. 2. Spot-wise number and percentage values of odonate species collected during the study period.

During the study period (Table 3, Fig. 3), highest species richness (SR) value was observed in May'17 (1.56 \pm 0.08$)$ and lowest in December'16 (0.96 \pm 0.05$)$. Species richness values ranged in Spot 1 from 0.76 to 1.66, in Spot 2 from 0.69 to 1.47, in Spot 3 from 0.74 to 1.70 and in Spot 4 from 0.81 to

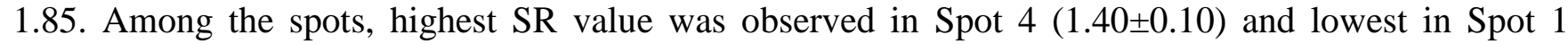
$(1.02 \pm 0.08)$. Highest species diversity $\left(\mathrm{H}^{\prime}\right)$ value was observed in May'17 (1.29 \pm 0.08$)$ and lowest in November' $16(0.90 \pm 0.02)$. Species diversity values ranged in Spot 1 from 0.88 to 1.27, in Spot 2 from 0.94 to 1.48, in Spot 3 from 0.88 to 1.36 and in Spot 4 from 0.66 to 1.45. Among the spots, highest $\mathrm{H}^{\prime}$ value was observed in Spot $2(1.22 \pm 0.05)$ and lowest in Spot $1(1.01 \pm 0.04)$. Highest species evenness 
$\left(\mathrm{J}^{\prime}\right)$ value was observed in December'16 (0.96 \pm 0.03$)$ and lowest in May'17 $(0.81 \pm 0.05)$. Species evenness values ranged in Spot 1 from 0.79 to 1.00, in Spot 2 from 0.70 to 0.97, in Spot 3 from 0.69 to 1.00 and in Spot 4 from 0.68 to 0.98 . Among the spots, highest $\mathrm{J}^{\prime}$ value was observed in Spot 1 $(0.93 \pm 0.02)$ and lowest in Spot $4(0.82 \pm 0.02)$.

Table 3. Monthly fluctuations in species richness $(\mathrm{SR})$, species diversity $\left(\mathrm{H}^{\prime}\right)$ and species evenness $\left(\mathrm{J}^{\prime}\right)$ of the collected odonate species in the study spots.

\begin{tabular}{|c|c|c|c|c|c|c|c|c|c|c|c|c|c|c|c|}
\hline \multirow[t]{2}{*}{ Month } & \multicolumn{5}{|c|}{ Species Richness(SR) } & \multicolumn{5}{|c|}{ Species diversity $\left(\mathrm{H}^{\prime}\right)$} & \multicolumn{5}{|c|}{ Species evenness $\left(\mathrm{J}^{\prime}\right)$} \\
\hline & Spot & Spot & Spot & $\begin{array}{c}\text { Spot } \\
4\end{array}$ & Total & Spot & Spot & Spot & $\begin{array}{c}\text { Spot } \\
4\end{array}$ & Total & Spot & Spot & Spot & $\begin{array}{c}\text { Spot } \\
4\end{array}$ & Total \\
\hline Aug'16 & 0.96 & 1.33 & 0.77 & 1.54 & $\begin{array}{c}1.15 \\
\pm 0.17\end{array}$ & 0.95 & 1.34 & 0.93 & 1.23 & $\begin{array}{c}1.11 \\
\pm 0.10\end{array}$ & 0.95 & 0.85 & 0.93 & 0.78 & $\begin{array}{c}0.88 \\
\pm 0.04\end{array}$ \\
\hline Sep'16 & 0.83 & 1.22 & 0.74 & 1.39 & $\begin{array}{c}1.05 \\
\pm 0.16\end{array}$ & 0.89 & 1.22 & 0.97 & 1.19 & $\begin{array}{c}1.07 \\
\pm 0.08\end{array}$ & 0.89 & 0.78 & 0.97 & 0.73 & $\begin{array}{c}0.84 \\
\pm 0.05\end{array}$ \\
\hline Oct'16 & 0.78 & 1.31 & 0.85 & 0.93 & $\begin{array}{c}0.97 \\
\pm 0.12\end{array}$ & 0.98 & 1.11 & 0.91 & 0.66 & $\begin{array}{c}0.92 \\
\pm 0.09\end{array}$ & 0.98 & 0.70 & 0.91 & 0.68 & $\begin{array}{c}0.82 \\
\pm 0.08\end{array}$ \\
\hline Nov'16 & 1.00 & 0.73 & 1.00 & 1.18 & $\begin{array}{c}0.98 \\
\pm 0.09\end{array}$ & 0.88 & 0.97 & 0.88 & 0.86 & $\begin{array}{c}0.90 \\
\pm 0.02\end{array}$ & 0.88 & 0.97 & 0.88 & 0.86 & $\begin{array}{c}0.90 \\
\pm 0.02\end{array}$ \\
\hline Dec'16 & 1.05 & 0.81 & 1.00 & 1.00 & $\begin{array}{c}0.96 \\
\pm 0.05\end{array}$ & 0.99 & 0.97 & 1.00 & 0.88 & $\begin{array}{c}0.96 \\
\pm 0.03\end{array}$ & 0.99 & 0.97 & 1.00 & 0.88 & $\begin{array}{c}0.96 \\
\pm 0.03\end{array}$ \\
\hline Jan'17 & 1.00 & 1.47 & 1.18 & 1.85 & $\begin{array}{c}1.38 \\
\pm 0.18\end{array}$ & 0.97 & 1.32 & 0.97 & 1.32 & $\begin{array}{c}1.15 \\
\pm 0.10\end{array}$ & 0.97 & 0.84 & 0.97 & 0.84 & $\begin{array}{c}0.91 \\
\pm 0.04\end{array}$ \\
\hline Feb'17 & 0.89 & 1.39 & 1.67 & 1.70 & $\begin{array}{c}1.41 \\
\pm 0.19\end{array}$ & 0.95 & 1.39 & 1.30 & 1.23 & $\begin{array}{c}1.22 \\
\pm 0.09\end{array}$ & 0.95 & 0.88 & 0.75 & 0.78 & $\begin{array}{c}0.84 \\
\pm 0.05\end{array}$ \\
\hline Mar'17 & 0.81 & 1.37 & 1.70 & 1.75 & $\begin{array}{c}1.41 \\
\pm 0.22\end{array}$ & 1.00 & 1.48 & 1.36 & 1.30 & $\begin{array}{c}1.28 \\
\pm 0.10\end{array}$ & 1.00 & 0.94 & 0.86 & 0.82 & $\begin{array}{c}0.91 \\
\pm 0.04\end{array}$ \\
\hline Apr'17 & 0.87 & 0.69 & 0.83 & 1.56 & $\begin{array}{c}0.99 \\
\pm 0.19\end{array}$ & 0.98 & 0.94 & 0.88 & 1.34 & $\begin{array}{c}1.03 \\
\pm 0.10\end{array}$ & 0.98 & 0.94 & 0.88 & 0.85 & $\begin{array}{c}0.91 \\
\pm 0.03\end{array}$ \\
\hline May’17 & 1.59 & 1.31 & 1.63 & 1.70 & $\begin{array}{c}1.56 \\
\pm 0.08\end{array}$ & 1.27 & 1.35 & 1.09 & 1.45 & $\begin{array}{c}1.29 \\
\pm 0.08\end{array}$ & 0.80 & 0.84 & 0.69 & 0.92 & $\begin{array}{c}0.81 \\
\pm 0.05\end{array}$ \\
\hline Jun'17 & 1.66 & 1.32 & 0.85 & 0.81 & $\begin{array}{c}1.16 \\
\pm 0.20\end{array}$ & 1.26 & 1.25 & 1.00 & 0.98 & $\begin{array}{c}1.12 \\
\pm 0.08\end{array}$ & 0.79 & 0.79 & 1.00 & 0.98 & $\begin{array}{c}0.89 \\
\pm 0.06\end{array}$ \\
\hline Jul'17 & 0.76 & 1.19 & 1.43 & 1.38 & $\begin{array}{c}1.19 \\
\pm 0.15\end{array}$ & 0.98 & 1.24 & 1.21 & 1.23 & $\begin{array}{c}1.17 \\
\pm 0.06\end{array}$ & 0.98 & 0.78 & 0.77 & 0.78 & $\begin{array}{c}0.83 \\
\pm 0.05\end{array}$ \\
\hline
\end{tabular}

A diversity index is a quantitative measure that reflects how many different types are there in a data set and simultaneously takes into account how evenly the basic entities are distributed among those types. Species richness of a data set is the number of different species in the corresponding species list. Species diversity indicates how diversified the species are and species evenness indicates how evenly distributed the species are in a locality. Communities with less variation in the relative abundance of species are considered more even than community with more variation in relative abundance. During the study period, in all the four spots, it was observed that species richness was negatively related with species evenness. The more species rich an area was, the less evenly distributed the species were. However, species diversity values varied with ecological conditions and as Spot 2 was a hotspot for the odonate species, the species diversity value was highest in this spot.

During monsoon (July'17), odonate abundance was high, as the monsoon being the major factor in density and distribution of plants leading to increase in the abundance of herbivorous insects, the prey of carnivorous ones. Thus, influence of rainfall in the form of humidity on density and diversity of population is likely to be an indirect effect operating via effects on availability. On the other hand, their abundance was low in the months of January'17, November'16 and December'16 due to unfavorable condition of weather of winter season. 


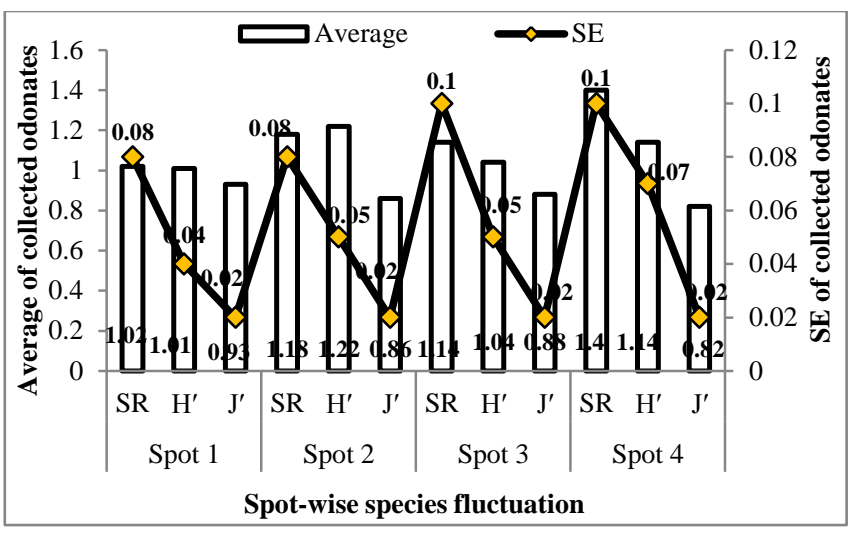

Fig. 3. Spot-wise species fluctuation in different spots during the study period.

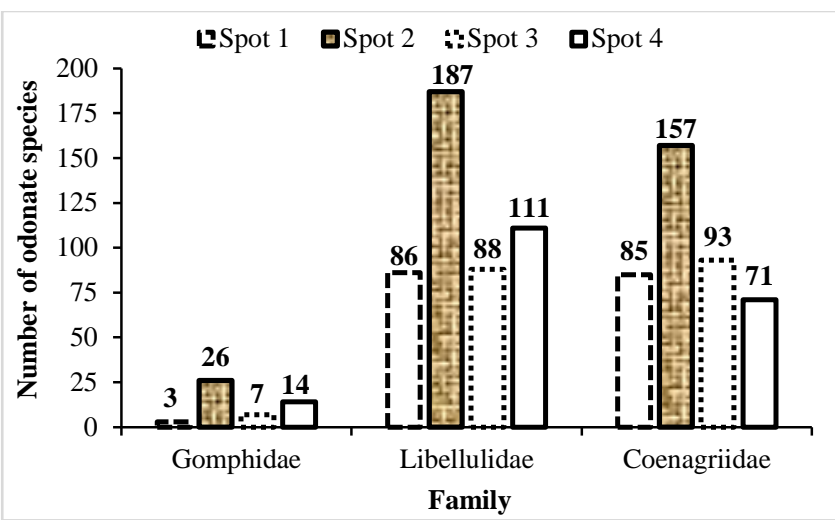

Fig. 4. Family-wise species collection in the four spots during the study period.

Highest species abundance spot was Spot 2. The reason is that the place with its submerged aquatic vegetations was an excellent place for the breeding of odonates. The species richness was highest in Spot 4, whereby, different types of odonate species were found. Shannon-Wiener index of diversity clearly indicated that the abundance and diversity of odonates was in a good state in Spot 2 indicating that this spot was very much suitable than the other three spots. However, species diversity values were low in Spot 1 and Spot 3, and hence in these spots, the odonate species were not so diversified. The odonate species were more or less evenly distributed in all the four spots, but species evenness value was highest in Spot 1 indicating the more even distribution of odonate species in this spot.

The species richness, species diversity and species evenness values fluctuated month wise randomly. The number of species fluctuated in different months of the year due to seasonal and other environmental factors. Environment was not strongly favourable for the survival and breeding of odonates during cold. Hence, species abundance was low in the months of November'16 and December'16. After the cold season, the number of odonates increased gradually with the increasing temperature of the environment. There was a rainfall in April'17. The water bodies filled with water and green vegetables and bushes became more attractive breeding sites of odonate species. At that time due to favorable environmental conditions, spots were suitable for the breeding of odonates and the number of odonate species reached its peak in the month of July'17.

The various environmental factors such as temperature, humidity, rainfall, vegetation and food sources directly affect the diversity and distribution of odonate population, which is also supported by Morais et al. (1999), Kittelson (2004), Bispo and Oliveira (2007) and Goldsmith (2007). And according to El-Moursy et al. (2001), there is little doubt that conditions like humidity, moisture, temperature etc. might affect insect distribution. On the basis of present study, it is clear that availability of odonate species was not only dependent on seasonal fluctuation, but also on ecological and environmental conditions. However, being biological indicators, their availability indicated good environmental quality.

\section{REFERENCES}

Bashar, K., M. S. Reza, M. A. Razzak, K. M. Z. Rahman, P. Goda and A. J. Howlader. 2014. Faunistic study on Odonata (Dragonfly and Damselfly) in some selected regions of Bangladesh. J. Entomol. Zool. Stud. 2(4): 1-6.

Begum, A., M. A. Bashar and V. Biswas. 1990a. The mating behaviour and development of Rhodothemis rufa (Rambur) (Anisoptera: Libellulidae). Indian Odonatol. 3: 1-9. 
Begum, A., M. A. Bashar and V. Biswas. 1990b. On the life history of Neurothemis tullia (Drury) from Dhaka, Bangladesh (Anisoptera: Libellulidae). Indian Odonatol. 3: 11-20.

Bispo, P. C. and L. G. Oliveria. 2007. Diversity and stucture of Ephemeroptera, Plecoptera and Trichoptera (Insecta) assemblages from riffles in mountain streams of Central Brazil. Revista Brasileira de Zoologia 24: 283-293.

Biswas, V., M. A. Bashar and A. Begum. 1990. On a collection of Odonata of Bagerhat district, Khulna, Bangladesh. Indian Odonatol. 3: 65-66.

Borror, D. J., D. M. Delong and C. A. Triplehorn. 1981. An Introduction to the study of Insects (5 ${ }^{\text {th }}$ ed.). Saunders College Publishing. New York. 827 pp.

Chowdhury, J. H. and O. Zenther. 1971. A intern result obtained in forest entomology section from July 1969 to August 1971. Forestdale News. 4(1): 49-61.

Chowdhury, S. H. and M. Akhteruzzaman. 1983. Some dragonflies (Odonata: Anisoptera) of Chittagong University Campus, Bangladesh- Part II. Chittagong Univ. Stud. 7(1): 39-48.

Chowdhury, S. H. and M. I. Miah. 1989. Notes on some damselflies (Odonata: Zygoptera) of Chittagong University Campus- Part II. Chittagong Univ. Stud. 13(1): 65-70.

Chowdhury, S. H. and M. Mohiuddin. 1993. New dragonflies from the Chittagong University Campus. Bangladesh J. Zool. 21(2): 149-150.

Chowdhury, S. H. and M. Mohiuddin. 1994. Dragonfly phenology- A mechanism for optimal habitat utilization. In: V. K. Srivastava. (ed.). Adv. Orient. Odontol., pp. 47-54.

Chowdhury, S. H. and M. Mohiuddin. 2011. A check-list of the Odonata from the eastern Region of Bangladesh with some taxonomic notes. Univ. J. Zool. Rajshahi Univ. 30: 61-66.

El-Moursy, A., M. El-Hawagry, M. Abdeldayem and H. Fadl. 2001. Insect diversity in Zaranik Protectorate, Northern Sinai, Egypt. Egyptian J. Nat. Hist. 3: 87-95.

Franz, D. R. 1976. Benthic molluscan assemblages in relation to sediment gradients in northeastern long Island Sound, Connecticut. Malacologia. 15(2): 377-399.

Fraser, F. C. 1933. The Fauna of British India including Ceylon and Burma. Odonata, Vol. I. Taylor and Francis, London. 423 pp.

Fraser, F. C. 1934. The Fauna of British India including Ceylon and Burma. Odonata, Vol. II. Taylor and Francis, London. 398 pp.

Fraser, F. C. 1936. The Fauna of British India including Ceylon and Burma. Odonata, Vol. III. Taylor and Francis, London. 461 pp.

Gleason, H. A. 1922. On the relation between species and area. Ecol. 3: 156-162.

Goldsmith, S. 2007. Density of long horned beetles (Coleoptera: Cerambycidae) differs at different elevations in Hawaiian montane forest. Southwestern. Nat. 52: 156-162.

Habib, M. S. A., M. Hossain, K. F. Iqubal, T. Khan, M. S. Islam, S. Saif and M. M. M. Jewel. 2016. Dragonflies and Damselflies of Bangladesh: Inventory First Phase. Jibon Bikash Karjocrom. 96 pp.

Kabir, S. M. H., M. Ahmad, A. T. A. Ahmed, A. K. A. Rahman, E. U. Haque, Z. U. Ahmed, Z. N. T. Begum, M. A. Hassan and M. Khondker (eds.). 2008. Encyclopedia of Flora and Fauna of Bangladesh, vol. 19. Apterygota and Pterygota. Asiatic Society of Bangladesh, Dhaka. 275 pp. 
Khan, M. K. 2015. Dragonflies and damselflies (Insecta: Odonata) of the Northeastern region of Bangladesh with five new additions to the Odonata fauna of Bangladesh. J. Threatened taxa. 7(11): 7795-7804.

Khan, M. K. 2017. Dragonflies of the eastern region of Bangladesh with four new addition to the Bangladeshi dragonfly fauna. bioRxiv. $28 \mathrm{pp}$.

Kittelsaon, P. M. 2004. Sources of variation in insect density on Lupinus arboreus Sims: effects of environment, source population and plant genotype. Am. Midland Nat. 152: 323-335.

Kumar, A. and M. Prasad. 1981. Field ecology, Zoogeography and taxonomy of Odonata of Western Himalaya, India. Rec. Zool. Surv. India. 20: 1-118.

Lahiri, A. R. 1987. Studies on the Odonata fauna of Meghalaya. Rec. Zool. Surv. India. 99: 1-402.

Mitra, T. R. 2002. Geographical distribution of Odonata (Insecta) of eastern India. Mem. Zool. Surv. India. 19(1): 1-208.

Morais, H. C., Diniz, I. R. and Silvia, D. M. S. 1999. Caterpillar seasonality in a central Brazilian cerrado. Revista de Biologia Tropical. 47: 1025-1033.

Nomura, S. and M. Z. Alam. 1995. A list of Dragonflies collected in Bangladesh. Esakia. 35: 135-140.

Pielou, E. C. 1966. The measurement of diversity in different types of Biological collections. J. Theort. Biol. 13: 131-144.

Richards, O. W. and R. G. Davies. 1977. Imms' General Textbook of Entomology. Vol. 2. 10th ed. Classification and Biology, Chapman and Hall, London, England. 1354 pp.

Shannon, C. E. and W. Wiener. 1949. The Mathematical Theory. University of Illinois press Urbana. $117 \mathrm{pp}$.

Silsby, J. 2001. Dragonflies of the world. Smithsonian Institution Press, USA, Washington DC. 216 pp.

Trueman, W. H. J. 2007. A brief history of the classification and nomenclauture of Odonata. Zootaxa. 1668: $381-394$.

Tsuda, S. 2000. A distributional list of world Odonata. Osaka Pref. 430 pp.

Tuhin, M. S. H. and M. K. Khan. 2018. Species richness, habitat association and odonata diversity of the south-western region of Bangladesh. bioRxiv, pp. 1-28.

Vick, G. S. 2002. Preliminary biodiversity assessment of odonate fauna of the Takamanda Forest Reserve, Cameroon. IDF-report 4., pp. 1-10.

\section{DOI: http://dx.doi.org/10.3329/jbcbm.v4i1.37877}

